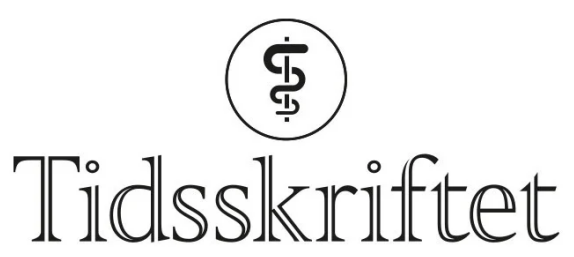

DEN NORSKE LEGEFORENING

\title{
Ikke glem den lille multiplikasjonstabellen
}

LEGELIVET

\section{KARL O. NAKKEN}

karln@ous-hf.no

Karl O. Nakken er dr.med., nevrolog og pensjonert overlege. Han var i mange år medisinsk ansvarlig ved Spesialsykehuset for epilepsi i Sandvika.

\section{Våre politikere bør minnes om at å investere i helse er å} investere i samfunnet. Money spent on the brain is never spent in vain, er et ordtak vi har i nevrologien.

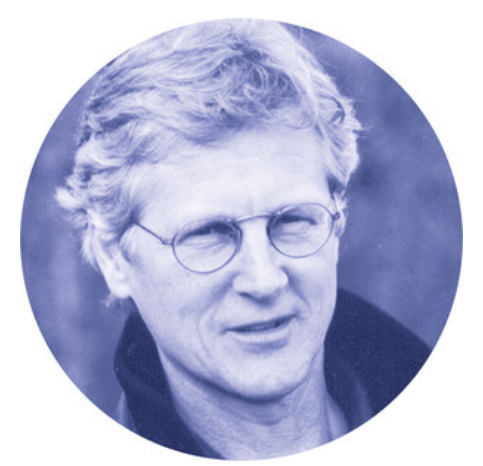

Foto: privat

I doktorklubben mener vi dagens norske helsevesen er overadministrert. Etter at markedstenkningen fikk rotfeste i offentlig forvaltning, har vi fått en stadig økende hær av byråkrater hvis eneste oppgave er å registrere og kontrollere andre - uten selv å ha noen faglig innsikt i kjerneoppgavene. Inkompetanse innebærer gjerne at den inkompetente er ute av stand til å se sin egen inkompetanse.

Nå for tiden oppsøker mange pasienter oss nærmest med et krav om konkrete undersøkelser, spesielt MR. Mange kolleger gir etter for kravet, uten egentlig å ha vurdert indikasjonen. I doktorklubben er vi enige om at mye av det vi lærte på doktorskolen for lengst er glemt, men noe husker vi: Dersom det er diskrepans mellom kliniske funn og svaret fra laboratoriet, er det klinikken vi må stole på. Med dagens avanserte bildediagnostiske metoder er det lett for at klinikken blir tilsidesatt.

Vi må ikke glemme den lille multiplikasjonstabellen. Fortsatt er det slik at en god sykehistorie i kombinasjon med klinisk undersøkelse gir rett diagnose i de fleste tilfeller. Å få mest mulig ut av sykehistorien krever imidlertid kunnskap, erfaring og tilstrekkelig tid 
med pasientene. I en heseblesende hverdag er jeg redd vi ofte etterlater pasientene med et inntrykk av at vi er stresset og travle og at de må fatte seg i korthet. Da kan verdifull diagnostisk informasjon gå tapt, og mange unødvendige undersøkelser blir rekvirert. Dyrt for samfunnet blir det også. Vi mener det er på høy tid at våre helsemyndigheter, med sin overdrevne opptatthet av det pekuniære, innser at det på sikt vil lønne seg å gi oss bedre tid med pasientene. Dessuten: Klinikken må få en renessanse.

\section{«Det er på høy tid at våre helsemyndigheter, med sin overdrevne opptatthet av det pekunicere, innser at det på sikt vil lønne seg å gi oss bedre tid med pasientene»}

Vi diskuterte hvorvidt en erfaren kliniker, trass i dårlig tid, likevel kan stille kjappe og riktige diagnoser, nærmest prima vista. Et medlem mente, trolig basert på egne erfaringer, at dersom en eldre person plutselig stanser opp, bøyer seg og later som hen knyter skolissene, så har hen garantert spinal stenose. Vi andre stilte oss tvilende til den lyndiagnostikken. Vi måtte minne om at det faktisk finnes personer med et reelt behov for å knyte lissene! Han lurte også på om firmaer som i stillingsannonser søker etter framoverlente personer, jakter på folk med spinal stenose?

Vi er digitale avholdsfolk. I hvert fall er vi måteholdne. I disse koronatider kan vi styre vår begeistring for digitale møter. Vi føler oss ofte som fremmedelementer i en høyteknologisk verden. Reminisenser fra en fjern fortid, en utrydningstruet rase. Blant annet hører vi til dem som fortsatt støtter skogindustrien ved å lese aviser og Tidsskriftet på papir. Enkelte av oss mente i starten av 1980-årene at data var en døgnflue. Senere har vi måttet bite i det sure gresset og erkjenne at datateknologien er et fantastisk verktøy. Så lenge det funker.

Vi deltar lite på sosiale medier. Den eneste som er på Facebook, hevder at man der kan lese om kjedelige trivialiteter, ofte ispedd patetisk selvskryt. Han var forbauset over at Trump langt fra er alene om stadig å måtte pleie sitt ego. Er narsissisme blitt langt vanligere i dag enn tidligere? Og er selvopptatthet de dummes bedøvelsesmiddel?

\section{«Er narsissisme blitt langt vanligere i dag enn tidligere? Og er selvopptatthet de dummes bedøvelsesmiddel?»}

Vi registrerer at dagens barn vokser opp bak en dataskjerm. Der vi nærmest måtte jages inn av våre foreldre, må barn av i dag jages ut. Bort fra skjermene. For oss ser det ut til at dagens barn lever et skjermet liv - i mer enn én forstand. Når vi i dag vet hvor stor betydning regelmessig fysisk aktivitet har for kognitive funksjoner, må det være grunn til å bekymre seg for barnets hippocampi.

Et klubbmedlem var nylig kommet til at han altfor lenge hadde latt kroppen ligge brakk. Gjennom mange år med stillesittende kontorarbeid hadde legemet forfalt. Han stusset over at kroppsvekten hadde $ø \mathrm{kt}$ til tross for omfattende inaktivitetsbetinget muskelatrofi. Dette aktet han å gjøre noe med. Han hadde meldt seg inn på et treningssenter med mål om å gå fra gretten gammel gubbe til spretten gammel gubbe. Etter første time trodde han at han kvalifiserte for diagnosen stiff man syndrome. Og hvor i all verden hadde spensten tatt veien? Han var blitt akkurat like spretten som en sementsekk. Han fortalte om tunge bein og tunge tanker. Nå vurderte han å gå over til en handikapaktivitet: Han ville melde seg inn i golfklubben Hvilepuls.

Publisert: 18. februar 2021. Tidsskr Nor Legeforen. DOI: 10.4045/tidsskr.21.0039

(C) Tidsskrift for Den norske legeforening 2023. Lastet ned fra tidsskriftet.no 26. april 2023. 